\title{
Epidemiological and clinical features in 165 cases of granuloma inguinale
}

\author{
SARD ARI LAL * AND C. NICHOLAS \\ From the Department of Venereal Diseases and Dermatology, \\ fawaharlal Institute of Post-Graduate Medical Education and Research, Pondicherry-6, India
}

Granuloma inguinale was first described in India by McLeod (1882) under the name of "serpiginous ulcer". The disease was later reported from various countries under different names, but there is still no unanimity regarding its nomenclature. Granuloma venereum is still preferred by some, but sexual transmission has been questioned by certain workers, notably Goldberg (1964). The aim of the present communication is to report clinical and epidemiological observations on 165 cases of the disease and to discuss the findings in relation to mode of transmission and nomenclature.

\section{Material and methods}

A total of 165 cases of granuloma inguinale was diagnosed in the venereal disease department of The Jawaharlal Institute, Pondicherry, during the period April, 1966 , to December, 1969. Diagnosis was made by the demonstration of "Donovan bodies" in tissue smears of material from ulcers, stained with Leishman stain.

\section{Observations}

PREVALENCE

Of 3,140 patients who attended the department for complaints relating to venereal diseases, 165 $(5 \cdot 3$ per cent.) were found to be suffering from granuloma inguinale.

AGE DISTRIBUTION (Table I)

76.4 per cent. of the patients were aged between 20 and 40 years, i.e., the period of maximum sexual activity.

TABLE I Age distribution

\begin{tabular}{|c|c|c|c|}
\hline Age (yrs) & Up to 19 & 20 to 40 & Above 40 \\
\hline $\begin{array}{l}\text { Number } \\
\text { Percentage }\end{array}$ & $\begin{array}{l}9 \\
5 \cdot 4\end{array}$ & $\begin{array}{l}126 \\
76 \cdot 4\end{array}$ & $\begin{array}{l}30 \\
18 \cdot 2\end{array}$ \\
\hline
\end{tabular}

Received for publication February 13, 1970.

Address for reprints: S. Lal, Assistant Professor, V.D. and Dermatology, H.P. Medical College, Simla 1, India.
SEX DISTRIBUTION

There were 115 males and 50 females. The ratio of males to females is about $2 \cdot 3: 1$, which is about the same as in other diseases known to be venereal.

MARITAL STATUS (Table II)

Most of the patients $(67 \cdot 3$ per cent.) were married.

TABLE II Marital status

\begin{tabular}{|c|c|c|c|}
\hline Marital status & Married & Unmarried & Others \\
\hline $\begin{array}{l}\text { Number } \\
\text { Percentage }\end{array}$ & $\begin{array}{l}111 \\
67.3\end{array}$ & $\begin{array}{l}38 \\
23 \cdot 0\end{array}$ & $\begin{array}{c}16 \\
9 \cdot 7\end{array}$ \\
\hline
\end{tabular}

DURATION OF DISEASE

This was below 1 month in 24 cases, between 1 and 2 months in 21 cases, and above 2 months in 120 cases. The longest duration was 8 years.

INCUBATION PERIOD

This varied from 3 days to 6 months. It was 3 days in three cases, 4 to 7 days in seven, 7 to 30 days in 66,31 to 60 days in eight, and more than 60 days in six. In the remaining 75 patients it could not be accurately determined. Rajam and Rangiah (1954) stated that, in their study of a limited series of early cases, the incubation period varied from 2 weeks to 1 month. Greenblatt, Dienst, Pund, and Torpin (1939) reported an incubation period ranging from 42 to 50 days, but Greenblatt (1943), in a later review of case reports, gave a range of 8 days to 12 weeks.

SITES INVOLVED (Table III, opposite)

The genitalia were involved in 92.7 per cent. of cases, the inguinal region in 9.7 per cent., and the anal region in 7.3 per cent. Lesions were limited to the genitalia in 137 cases (83 per cent.), and to the inguinal region in five cases ( 3 per cent.). In a study of 858 cases, Rajam and Rangiah (1954) reported genital lesions in about 90 per cent. of cases and 
inguinal lesions in about 25 per cent. Lal, Padma, and Velou (1967), in a study of 85 cases, reported genital lesions in 93 per cent. cases and inguinal lesions in 11 per cent.

TABLE III Distribution of sites affected

\begin{tabular}{lccc}
\hline Site & & Number & Percentage \\
\cline { 1 - 3 } \cline { 3 - 4 } Genitalia & 153 & $92 \cdot 7$ \\
Inguinal regions & 16 & $9 \cdot 7$ \\
Anal region & 12 & $7 \cdot 3$ \\
Oral cavity & 3 & $1 \cdot 8$ \\
\hline
\end{tabular}

ASSOCIATED VENEREAL DISEASES

Syphilis was found in 45.5 per cent. of cases, 14.5 per cent. were infected with lymphogranuloma venereum, and 1.2 per cent. with gonorrhoea.

EXAMINATION OF SEXUAL PARTNERS (Table IV)

For various reasons, only fifty sexual partners were available for examination, all of whom were marital partners. In 26 partners (52 per cent.), granuloma inguinale was proved and in six other persons there were ulcers suggestive of the disease but the organisms could not be demonstrated in tissue smears. Eight others showed evidence of other types of venereal disease. Ten others showed no evidence of venereal disease but two of these had not had sexual contact with their marital partners since the onset of their disease, and in four cases the duration of disease in the patients was 2 months or less.

Rajam and Rangiah (1954) observed thirty cases of infection in the sexual partner among 250 cases examined between 1950 and 1953.

Serma (1957) found nineteen cases of conjugal granuloma inguinale among 157 cases of the disease. It must be stressed that conjugal infection with granuloma inguinale is not as uncommon as has been claimed by some workers, although its detection requires considerable effort.

TABLE IV Findings in marital partners

\begin{tabular}{|c|c|c|c|}
\hline \multicolumn{2}{|l|}{ Diagnosis } & \multirow{2}{*}{$\frac{\text { Number }}{26}$} & \multirow{2}{*}{$\begin{array}{l}\text { Percentage } \\
52\end{array}$} \\
\hline Granuloma inguinale & Proved & & \\
\hline & Suspected & 6 & 12 \\
\hline \multicolumn{2}{|l|}{ Other venereal diseases } & 8 & 16 \\
\hline \multicolumn{2}{|l|}{ No disease } & 10 & 20 \\
\hline
\end{tabular}

\section{Discussion}

MODE OF TRANSMISSION

Goldberg (1964) has argued strongly against the sexual transmission of this disease, but our observations favour the venereal spread of this infection for the following reasons:
(1) A clear history of sexual exposure before the appearance of the ulcer in the majority of the male patients.

(2) The largest proportion of the patients (76 per cent.) at the age of maximum sexual activity.

(3) The ratio of males to females $(2 \cdot 3: 1)$.

(4) The situation of the lesions on the genitalia in 93 per cent.; and on the genitalia only, in 83 per cent. of cases.

(5) The presence of other types of venereal disease in a substantial number of patients, e.g. syphilis in 45.5 per cent.

(6) The presence of the disease in 52 per cent. of fifty marital partners examined, and of suspected infection in a further 12 per cent.

\section{NOMENCLATURE}

The "International Classification of Diseases" (WHO, 1967) mentions the names: Granuloma inguinale, Donovanosis, Granuloma pudendi (ulcerating), and Granuloma venereum. The term "Granuloma inguinale", though generally accepted, is unsatisfactory because of the infrequency of the lesion in the inguinal regions. The term "Donovanosis" gives the impression that this is a systemic disease like Leishmaniasis or Filariasis, although systemic cases are rarely seen. We suggest that the term "Granuloma Donovani" may be more acceptable; it prevents criticism by those who doubt the venereal spread of the disease, it perpetuates the name of Donovan (1905), who first discovered the causative organisms, and it avoids the implication that the lesions are confined to the inguinal regions.

\section{Summary}

Epidemiological and clinical features of 165 cases of granuloma inguinale are reported. The occurrence of conjugal infection in 52 per cent. of fifty marital partners and the concurrence of syphilis in 45.5 per cent. of all cases strongly favour sexual transmission.

"Granuloma Donovani" is suggested as a more acceptable name for this disease.

We are grateful to the Principal of our Institute for permission to report these observations.

\section{References}

Donovan, C. (1905) Indian med. Gaz., 40, 411

GoldBerg, J. (1964) Brit. F. vener. Dis., 40, 140

GreENBLATT, R. B. (1943) "Management of Chancroid, Granuloma Inguinale, and Lymphogranuloma Venereum in General Practice", p. 17. U.S. Government Printing Office, Washington, D.C.

, Dienst, R. B., Pund, E. R., and Torpin, R. (1939) F. Amer. med. Ass., 113, 1109 
Lal, S., Padma, N. S., and Velou, A. (1967) Indian $\mathcal{F}$. Derm. Vener., 33, 65

MCLEOD, K. (1882) Indian med. Gaz., 17, 113

RAJAM, R. V., and RANGIAH, P. N. (1954) "Donovanosis (Granuloma Inguinale, Granuloma Venereum)". W.H.O. Monograph Series No. 24, Geneva

Serma, J. S. (1957) Indian f. Derm. Vener., 23, 9

WHO (1967) "Manual of the International Statistical Classification of Diseases, Injuries, and Causes of Death". Geneva
Etude de 165 cas de granulome inguinal SOMMAIRE

On rapporte les constatations épidémiologiques et cliniques faites sur 165 cas de granulome inguinal. L'infection concomitante de 52 pour cent des 50 partenaires conjugaux, et l'existence simultanée de la syphilis dans 45,5 pour cent du total des cas, est fortement en faveur du rôle de la transmission sexuelle.

On considère que 'Granuloma donovani' est un nom plus approprié pour cette maladie. 